\author{
Re St John the Baptist, Barlaston \\ Lichfield Consistory Court: Eyre Ch, 29 December 2017 \\ [2017] ECC Lic 7 \\ Reservation of grave space - PCC policy
}

Miss Winnett petitioned for the reservation of a grave space in the churchyard, which would be full in the next 20 to 25 years. Prior to her application the Parochial Church Council (PCC) had adopted a policy against reservations on the basis of the limited space available in the churchyard. Miss Winnett argued that her petition should be granted despite the PCC policy on two grounds: first, that it was unfair that no advance notice had been given of the adoption of the PCC policy; and second, that her personal connection with the churchyard was such as to justify an exception to the policy. Miss Winnett had lived in a house overlooking the churchyard for 51 years; she regularly visited the grave of her mother there, with whom she had lived and for whom she had cared; her father's remains would be buried there in due course. The chancellor confirmed his earlier approach that such PCC policies would be given great weight if it could be shown, as here, that they were reasonable and had not been adopted to thwart a particular application. To have given advance notice of the adoption of the policy would have run the risk of a flurry of applications which would compound the problem which the policy was design to address. Although Miss Winnett undoubtedly had a close relationship with the churchyard, to grant her petition would be to cause distress to those who were turned away from the churchyard while empty reserved spaces remained available. The petition was refused. [RA]

doi:10.1017/So956618X18000765

\title{
Re Romsey Abbey
}

Winchester Consistory Court: Ormondroyd Ch, 3 January 2018 [2018] ECC Win 1

Work of art - consultation - benefits outweighing status quo

Romsey Abbey is a Grade I listed church. St Etheldflaeda was the Abbess in around $1000 \mathrm{CE}$ and is, along with the Blessed Virgin Mary, a patron saint of the abbey. In 2016 the abbey hosted an exhibition of paintings by Christopher Gollon, which included, as a bespoke addition, the diptych of St Ethelflaeda. The diptych is a piece of modern art, depicting the saint and a candle. According to the artist it is designed to be 'challenging and controversial' while inviting worshippers to contemplate the saint's serenity and to reflect on their own faith. It was designed to be hung against the backdrop of two 